\section{Composted Yard Waste Affects Soil Displacement and Roadside Vegetation}

\author{
Michael S. Harrell and Grady L. Miller ${ }^{1}$ \\ Department of Environmental Horticulture, University of Florida, Gainesville, \\ FL 32611-0670
}

Additional index words. turfgrass, erosion, mulch, groundcover, bermudagrass, bahiagrass, asiatic jasmine

\begin{abstract}
The benefits of composted yard waste applied as a mulch were demonstrated in a field study at two locations and supporting greenhouse research. Compost was applied to eroded roadside slopes of about $12^{\circ}$ and $27^{\circ}$ to determine the influence on soil displacement and establishment and/or enhancement of permanent roadside vegetation. Treatments consisted of compost rates of $5 \mathrm{~cm}$ and planted with asiastic jasmine (Trachelopermum asiaticum), 5 and $10 \mathrm{~cm}$, seeded with 110 or $220 \mathrm{~kg} \cdot \mathrm{ha}^{-1}$ 80:20 bahiagrass (Paspalum notatum Flugge): bermudagrass (Cynodon dactylon $\mathrm{L}$.) seed mix by weight, straw erosion control mats, and bahiagrass sod. Compost treatments effectively controlled soil displacement regardless of compost rate or seeding with turfgrass at both locations. Effects on roadside vegetation and visual quality varied with location. Asiatic jasmine did not establish at either site. Compost mulch applications increased total vegetation, turfgrass density, and quality at the site with $27^{\circ}$ slope and $4 \%$ initial soil organic matter content, but resulted in a decline in cover at the site with a $12^{\circ}$ slope and $<1 \%$ organic matter content. Compost mulch can effectively prevent soil displacement from roadside slopes, but may not promote establishment or enhancement of permanent vegetative cover.
\end{abstract}

Exposed soil along roadways is commonly found after road construction or periods of extended drought. Steep exposed slopes represent potential erosion problems if left untreated. Conventional methods of erosion control such as synthetic erosion control blankets and turfgrass sod can be labor intensive and costly to install.

Turfgrass establishment plays an important role in slope stability. Raindrop impact erodes any unprotected surface and initiates transport of detached particles (Mutchler et al., 1994). The matrix of stems and roots characteristic of turfgrass is ideal for holding soil in place and reducing the ability of rainfall to detach and move particles (Robinson et al., 1996). Roots near the surface improve surface porosity and increase water infiltration, preventing soil from becoming saturated and unstable (Carroll, 1992).

While turfgrass has been shown to effectively control erosion (Krenitsky et al., 1998), establishment on steep slopes can be difficult. Temporary erosion control measures have been used successfully to protect seed, soil, and fertilizers from the impact of rainfall (Collier et al., 1997). Carrol (1992) found that manmade erosion control materials such as shaved wood, jute, or fiber based mats reduced sediment losses by $94 \%$ to $99 \%$ of those from bare soil. However, these materials are intended for temporary erosion reduction until a permanent vegetative stand can be established.

One possible solution to controlling erosion and establishing permanent vegetation is to use composted yard waste as a mulch on steep

Received for publication 3 June 2005. Accepted for publication 25 July 2005. Journal paper R-10982, Univ. of Florida Agricultural Experiment Station.

${ }^{1}$ To whom reprint requests should be addressed; e-mailgmiller@mail.ifas.ufl.edu. slopes. Compost applied as a mulch can protect exposed soil from erosion (Ettlin and Stewart, 1993). Composts have shown beneficial effects on soil physical and chemical properties ( $\mathrm{He}$ et al., 1992; Giusquiani et al., 1995) and can be a useful soil amendment for plant growth if combined with a nitrogen source (Kostewitcz, 1993; Stevens and Kostewicz, 1992, 1994).

Legislation in the last decade has banned the landfilling of yard waste in many states (Steutville, 1995). Florida produces yard waste throughout the year unlike the northern states which produce it mainly in the summer and fall. The composting facility of Palm Beach County, Fla., produced about 200,000 t of yard waste compost in 2000 (Oshins and Block, 2000). Finding useful applications for the large quantities of composted materials produced can be a challenge. The objective of this study was to determine the effectiveness of composted yard waste at specific rates to control erosion and facilitate turfgrass establishment on steep roadside slopes compared to other erosion control measures.

\section{Materials and Methods}

Field study. A field study was conducted from 1 May 2000 through 1 Nov. 2001 to evaluate the effectiveness of composted yard waste sites were located near Kissimmee, Fla. (central site), at the intersection of US27 and US192 (81 $\left.{ }^{\circ} \mathrm{W} 40^{\prime} 39^{\prime \prime} 28^{\circ} \mathrm{N} 20^{\prime} 54^{\prime \prime}\right)$ and near Crescent Beach, Fla. (northern site), at the intersection of SR 206 and Interstate $95\left(81^{\circ} \mathrm{W} 21^{\prime} 21^{\prime \prime} 29^{\circ} \mathrm{N}\right.$ $\left.44^{\prime} 10^{\prime \prime}\right)$. Before treatment initiation, the sites were evaluated for vegetative cover, slope, and soil physical characteristics. Soils were typical disturbed material found on road shoulders. Soils at the central site contained $<1 \%$ organic content while the soil at the northern for controlling erosion on roadside slopes. Test site contained about $4 \%$ organic content as determined by weight loss on ignition ( 450 ${ }^{\circ} \mathrm{C}$ for $24 \mathrm{~h}$ ). Both soils were predominantly sand with greater than $80 \%$ of the particles falling into the medium sand category ( 150 to $250 \mu \mathrm{m}$ ) for the central site and $>95 \%$ for the northern site. Studies were conducted on slopes with existing thin stands of bahiagrass (Paspalum notatum Flugge) and bermudagrass (Cynodon dactylon L.). Initial turfgrass stands were $<20 \%$ cover for the central site and $<45 \%$ cover for the northern site.

Treatments at the central site were $5 \mathrm{~cm}$ compost mulch planted with asiatic jasmine (Trachelospermum asiaticum Sieb. et Zucc) groundcover on 30 -cm centers, $5 \mathrm{~cm}$ compost mulch with the standard Florida Department of Transportation (FDOT) seeding rate of 110 $\mathrm{kg} \cdot \mathrm{ha}^{-1}$ 80:20 bahiagrass:bermudagrass seed mix by weight, $5 \mathrm{~cm}$ compost mulch with double the FDOT standard seeding rate, $10 \mathrm{~cm}$ compost mulch with standard FDOT seeding rate, and $10 \mathrm{~cm}$ compost mulch with double the standard FDOT seeding rate, $\mathrm{SC}-150$ straw erosion control mat with standard FDOT seeding rate, erosion control mat with double the standard FDOT seeding rate, and a bahiagrass sod treatment. Asiatic jasmine groundcover was included to determine its suitability for use in high visibility areas for improved aesthetic quality. Plots were $3.0 \mathrm{~m}$ wide with a slope length of $10.0 \mathrm{~m}$. Slope of the test plots was about $12^{\circ}(21 \%)$ facing west.

Treatments at the northern site were: bare soil control, bare soil with $110 \mathrm{~kg} \cdot \mathrm{ha}^{-1} 80: 20$ bahiagrass:bermudagrass seed mix (standard FDOT seeding rate), bare soil with double seeding rate, $5 \mathrm{~cm}$ compost mulch planted with asiatic jasmine groundcover on $30-\mathrm{cm}$ centers, $5 \mathrm{~cm}$ compost with standard seeding, $5 \mathrm{~cm}$ compost mulch with double seeding rate, $10 \mathrm{~cm}$ compost mulch with standard seeding, and $10 \mathrm{~cm}$ compost mulch with double seeding rate This site was on the embankment of the Interstate 95 overpass over SR206. Plots were $3.0 \mathrm{~m}$ wide with a slope length that ranged from 10.0 to $14.0 \mathrm{~m}$ due to the tapering of the embankment from north to south. Slope of the test plots ranged from $26^{\circ}$ to $27^{\circ}$ (49\% to $51 \%$ ). Sod and erosion mat treatments (used at the central site) were replaced with bare soil treatments because without complete reworking of the slope to smooth the surface, these treatments would not have been practical. Bare soil treatments were substituted for these treatments at the request of FDOT. Reconstruction of the slope was contrary to the aim of this experiment.

Composted yard waste treatments were applied with a blower truck. Stakes marked at 5 and $10 \mathrm{~cm}$ were inserted into the test plots before compost application to insure uniform compost application depths. Seeds were surface applied and incorporated into compost treatments by hand raking. Test design was a randomized complete block with eight treatments and four replications.

Yard trimmings (tree and shrubbery trimmings, grass clippings, and leaves from homeowners and landscaping firms) compost was provided by Enviro-Comp Services Inc. 
(Jacksonville, Fla.) was used in this experiment. Rooted asiatic jasmine groundcover plants were transplanted from $10-\mathrm{cm}$ pots.

Irrigation water (unknown volume) was applied with a tanker truck and truck mounted nozzle to sod and groundcover treatments to prevent desiccation as perFDOT specifications (FDOT, 2000). Plots were only irrigated at the onset of the experiment. Test plots were not mowed and received only minor weeding as necessary to improve aesthetic quality. Due to insufficient rainfall, many of the groundcover plants died and were replanted October 2000. Since the plants died from lack of rainfall, the same planting protocol as previously reported was used.

At the time of compost delivery, two to six random grab samples were taken and combined. Composite sample were then analyzed in duplicate for specific physical and chemical properties and averaged. Bulk densities for compost samples were determined by filling a $500-\mathrm{mL}$ cylinder (9-cm inside diameter). The sample was then shaken to settle but not compact the material, then more sample was added until the desired volume was attained. The recorded mass was divided by the volume to calculate bulk density. Bulk density measurements may not be identical to field bulk densities due to the variations in settling over time in the field and potential sidewall effects from the cylinder. Percent moisture was determined as weight loss upon drying at $105{ }^{\circ} \mathrm{C}$ for $24 \mathrm{~h}$ divided by the mass of dry sample. Other samples were homogenized using Ultra-Turrax T25 (Labortechnik) and then analyzed for $\mathrm{N}$ content as received at the Suwannee Valley REC Livestock Waste Testing Laboratory (Live Oak, Fla.) using the semi-micro Kjeldahl method (Bremner and Mulvaney, 1982). The $\mathrm{pH}$ in water was determined with a glass electrode using a 1 sample $: 2.5$ water ratio (McLean, 1982).

Percent cover and visual quality were estimated by at least two raters and averaged on a monthly basis (Morris and Shearman, 2001). Percent cover was estimated visually by determining the area of all plant species (grasses and broadleaf weeds) within the plot divided by the total area of the plot. Quality data were determined using a visual scale of 1 to 9 , with $9=$ the highest quality and 5 $=$ minimally acceptable. Factors that where considered with regard to quality were density, uniformity, and presence of broadleaf weeds and weedy grasses.

A silt fence was constructed along the foot of the slope to contain any eroded soil from the test plots. After one year, the silt fence was removed, and eroded soil was collected and weighed. Sediment loss data are reported for the northern site only, since no measurable erosion occurred at the central site due to lesser slope and treatment selection. Another system of $1.5 \mathrm{~m}$ wide silt fence catchments was installed at the northern site $8 \mathrm{~m}$ below the top of the slope on each plot 3 June 2001. This was done to reduce the likelihood of damage from mowers and other equipment operating near the foot of the slope and to reduce the effect of soil erosion from neighboring plots. These catchments were installed by burying the lower $15 \mathrm{~cm}$ of the material, folding down the slope, and then staking the sides $30 \mathrm{~cm}$ downhill from the buried section. This created a pocket to catch any eroded soil and facilitate collection and measurement.

Following repeated destruction of on-site rainfall gauges, rainfall data were obtained from the Florida Automated Weather Network. Data for the northern site were taken from the agricultural experiment station located about $16 \mathrm{~km}$ from the research site in Hastings, Fla. Data for the central site were taken from the agricultural experiment station located about $20 \mathrm{~km}$ from the research site in Lake Alfred, Fla. Due to the distance from weather station to research site, these data were not sufficient to indicate on-site rainfall intensity. Observations of vegetation condition in the paired locations indicated the rainfall data of the remote site provided a reasonable estimate rainfall received on the research site over time.

Data were analyzed by ANOVA procedure using SAS statistical software (SAS Institute, Cary, N.C.). All reported differences were significant at $P \leq 0.05$. Means were separated with Duncan's LSD. Single degree of freedom comparisons of treatments were made using orthogonal contrasts.

Greenhouse study. A 12-week bahiagrass and bermudagrass establishment trial was conducted in a glasshouse at the Turfgrass Envirotron in Gainesville, Fla., to evaluate the effectiveness of seeding practices when using composted yard waste mulch and erosion control mats. This was done to determine if soil to seed contact would be sufficient for seed germination. Treatments consisted of seed applied to the surface of the erosion mat or compost mulch, seed incorporated into the top $4 \mathrm{~cm}$ of the compost mulch, and seed placed beneath the erosion control mat. Studies were conducted in 15-cm-diameter $\left(182 \mathrm{~cm}^{2}\right.$ planted surface area) pots with sand (60\% medium sand) and $10 \%$ peat using the 80 bahiagrass : 20 bermudagrass mix seeded at standard FDOT rate of $110 \mathrm{~kg} \cdot \mathrm{ha}^{-1}$ (FDOT, 2000) A completely randomized design was used with four treatments and four replications.
Plants which emerged and grew to a height of $>2 \mathrm{~cm}$ were recorded at 2 -week intervals for each container. Irrigation was applied at two 5-min intervals ( $8 \mathrm{~mm}$ total) per day from initiation through week 8 at which time the irrigation was applied at one 2-h interval (96 $\mathrm{mm}$ total) daily for the last four weeks to simulate heavy summer rainfall. Data were analyzed by ANOVA procedure using SAS statistical software. Means were separated with Duncan's LSD.

\section{Results and Discussion}

Selected characteristics of composts used at the north and central sites are shown in Table 1. Compost samples were generally similar for percent moisture, $\mathrm{pH}$, and total N. Bulk densities varied up to $20 \%$, likely due to the difficulty in sampling the coarse, heterogeneous material.

Total vegetation: Central site. Due to significant date, treatment, and date $\times$ treatment interactions (Table 2), treatment changes were analyzed over time for total vegetation and presented in Fig. 1. There was no difference in total vegetation between standard and double seeding rate treatments (Table 3 ). High compost rates were generally not different from low compost rates with the exception of 2 months during the first year and 3 months during the second year when low rates had greater total vegetation. This can likely be attributed to the burying of existing vegetation with the higher compost rate covering a larger percentage of preexisting cover. Increased rainfall during the second year facilitated increased vegetation for all treatments. Total vegetation for erosion mat treatments and compost treatments were not different for 8 of the first 9 months of the study, but erosion mat treatments exhibited greater vegetative cover in the last 9 months. Erosion mats allowed more sunlight to penetrate the soil than compost treatments, and may have resulted in greater germination and growth of weed and grass seeds. Sod treatments had greater total vegetation than compost and erosion mat treatments throughout the study. Compost rates of $5 \mathrm{~cm}$ were not different from

Table 1. Measured values and standard errors for bulk density, percent moisture, $\mathrm{pH}$, and total $\mathrm{N}$ (as received basis) of yard waste compost applied at north and central sites on Florida roadsides.

\begin{tabular}{lcccc}
\hline & $\begin{array}{c}\text { Bulk } \\
\text { density } \\
\left(\mathrm{g} \cdot \mathrm{cm}^{-3}\right)\end{array}$ & $\begin{array}{c}\text { Moisture } \\
(\%)\end{array}$ & $\mathrm{pH}$ & $\begin{array}{c}\text { Total } \\
\mathrm{N}\end{array}$ \\
Location & $0.25 \pm 0.03$ & $27.3 \pm 0.26$ & $5.7 \pm 0.1$ & 5 \\
\hline Northern site & $0.30 \pm 0.01$ & $28.3 \pm 0.33$ & $5.8 \pm 0.1$ & 5 \\
Central site & &
\end{tabular}

Table 2. Mean squares for the primary dependant variables and interactions at the central Florida site during 2000 and 2001. Main variable date consisted of monthly evaluations and treatments were vegetation establishment strategies.

\begin{tabular}{lrcr}
\hline Source & df & $\begin{array}{c}\text { Total } \\
\text { vegetation }\end{array}$ & $\begin{array}{c}\text { Total } \\
\text { quality }\end{array}$ \\
\hline Date & 17 & $5366.55^{* * *}$ & $13.32^{* *}$ \\
Replication & 3 & $8518.07^{* * *}$ & $109.65^{* *}$ \\
Treatment & 7 & $9232.16^{* *}$ & $98.67^{* *}$ \\
Date $\times$ replication & 51 & $185.04^{* * *}$ & $1.16^{* *}$ \\
Date $\times$ treatment & 119 & $171.46^{* * *}$ & $1.27^{* *}$ \\
Replication $\times$ treatment & 21 & $807.20^{* * *}$ & $9.44^{* *}$ \\
Error & 357 & 52.52 & 0.57 \\
Coefficient of variation $(\%)$ & & 15.3 & 18.6 \\
\hline
\end{tabular}

${ }^{* *}$ Significance at the 0.01 level of probability. 
groundcover treatments except for 4 months following replanting where groundcover treatments exhibited greater total vegetation. Total vegetation declined sharply in March 2001 for all treatments after an extended period of low rainfall beginning October 2000. By March 2001 all groundcover plants had died.

Total quality: Central site. Standard and double seeding rates had no effect on total quality at any time during the study (Table 3 ). High compost mulch rates were not different from low compost rates for all but one rating period. Total quality for erosion mat treatments and compost mulch treatments were not different for 8 of the first 9 months of the study, but erosion mat treatments exhibited higher quality for the last 9 months due to greater turfgrass cover. Sod treatments had greater total quality than compost mulch and erosion mat treatments throughout the study. Mulch rates of $5 \mathrm{~cm}$ were not different from groundcover treatments for all but two rating periods immediately following replanting where groundcover treatments exhibited higher quality. Groundcover plants died 3 months after replanting.

Mean separations at the conclusion of the study did not show significant differences between high and low seeding rates for $5 \mathrm{~cm}$ compost, $10 \mathrm{~cm}$ compost, and erosion mat treatments (Table 4). Seed germination was likely affected by limited rainfall following treatment applications (Fig. 2.)

Total vegetation: Northern site. Due to significant date, treatment, and date $\times$ treatment interactions (Table 5), treatment effects over time are represented in Figs. 3 and 4. Total vegetation of standard and double seeding rates was not different with the exception of 2 months during the first year where double seeding rates had greater cover. The bare soil treatment had similar total vegetation to seeded bare soil treatments for all but one rating period indicating that seeding of bare soil on roadside slopes is largely ineffective. Compost rates of $5 \mathrm{~cm}$ had greater total vegetation than $10-\mathrm{cm}$ rates for 7 of the first 10 months of the study. These treatments showed no difference for the remaining 8 months. Increased rainfall during the second year resulted in increased vegetation for all treatments at which point 5 and $10 \mathrm{~cm}$ compost treatments reached maximum cover

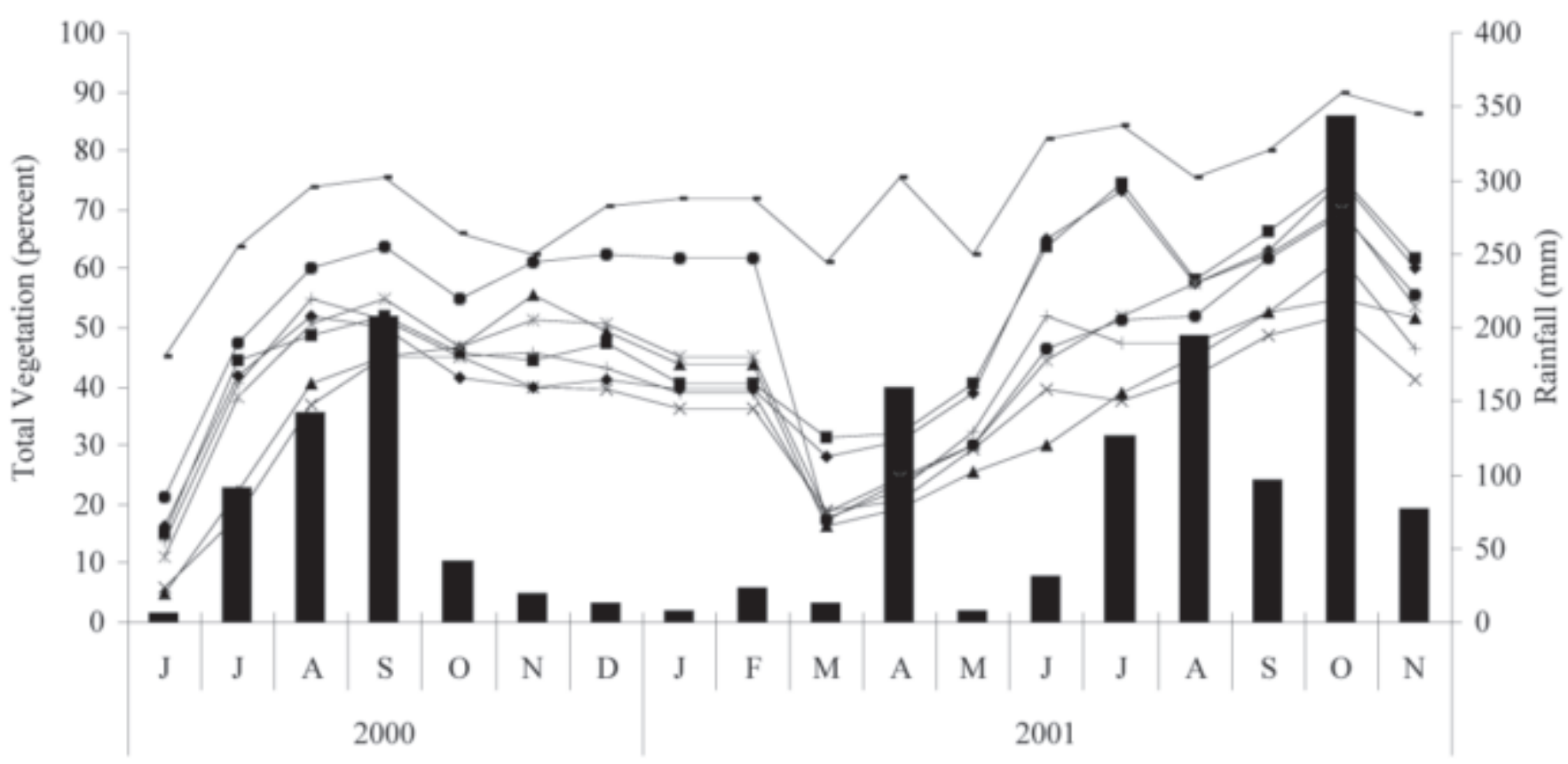

Time (month

Rainfall $\rightarrow$ Erosion mat double seeding - Erosion mat standard seeding
$-10 \mathrm{~cm}$ compost double seeding $\rightarrow-10 \mathrm{~cm}$ compost standard seeding $* 5 \mathrm{~cm}$ compost double seeding
$-5 \mathrm{~cm}$ compost ground cover $\longrightarrow 5 \mathrm{~cm}$ compost standard seeding - Bahiagrass sod

Fig. 1. Percent total vegetation and rainfall over 18 months in 2000 and 2001 at the central Florida site. Total vegetation included grass and weed species. Nearly all groundcover plants died and were replanted October 2000.

Table 3. Single degree of freedom orthogonal contrasts between treatments for total vegetation and total quality at the central site for $2000-01$.

\begin{tabular}{|c|c|c|c|c|c|c|c|c|c|c|c|c|c|c|c|c|c|c|}
\hline \multirow[b]{3}{*}{ Total vegetation ${ }^{z}$} & \multicolumn{18}{|c|}{ Month } \\
\hline & \multicolumn{7}{|c|}{2000} & \multicolumn{11}{|c|}{2001} \\
\hline & June & July & Aug. & Sept. & Oct. & Nov. & Dec. & Jan. & Feb. & Mar. & Apr. & May & June & July & Aug. & Sept. & Oct. & Nov. \\
\hline Standard vs. double seeding & NS & NS & NS & NS & NS & NS & NS & NS & NS & NS & NS & NS & NS & NS & NS & NS & NS & NS \\
\hline Erosion mat vs. compost & NS & $*$ & NS & NS & NS & NS & NS & NS & NS & ** & ** & ** & ** & ** & $*$ & $*$ & ** & $*$ \\
\hline Sod vs. compost & ** & ** & ** & ** & ** & $*$ & ** & ** & $* *$ & ** & ** & ** & ** & ** & ** & $* *$ & ** & ** \\
\hline Erosion mat vs. sod & $* *$ & $* *$ & $* *$ & $* *$ & $* *$ & $* *$ & $* *$ & $* *$ & $* *$ & $* *$ & $* *$ & $* *$ & $*$ & $*$ & $* *$ & $*$ & $*$ & $* *$ \\
\hline Groundcover vs. $5 \mathrm{~cm}$ compost & NS & NS & NS & NS & NS & $*$ & $*$ & $* *$ & $* *$ & NS & NS & NS & NS & NS & NS & NS & NS & NS \\
\hline Compost, 10 vs. $5 \mathrm{~cm}$ & ns & $*$ & NS & NS & NS & NS & NS & NS & NS & NS & NS & NS & NS & NS & NS & NS & NS & NS \\
\hline Erosion mat vs. compost & ** & NS & NS & NS & NS & NS & NS & NS & NS & $*$ & $*$ & $*$ & ** & ** & NS & ** & ** & $*$ \\
\hline Sod vs. compost & ** & ** & ** & ** & ** & ** & $* *$ & ** & ** & ** & $* *$ & ** & ** & ** & ** & ** & ** & $* *$ \\
\hline Mat vs. sod & * & ** & ** & ** & ** & ** & ** & ** & ** & ** & ** & ** & ** & ** & ** & ** & * & ** \\
\hline Groundcover vs. $5 \mathrm{~cm}$ compost & NS & NS & NS & NS & NS & * & * & NS & NS & NS & NS & NS & NS & NS & NS & NS & NS & NS \\
\hline
\end{tabular}

${ }^{2}$ Total vegetation included grass, weed, and groundcover plants. Most groundcover plants died or were covered by weeds.

yRatings of total quality were assessed using a 1 to 9 scale, with $9=$ the highest density, best uniformity, and no undesirable species.

${ }^{*, * *}$ Significance at the 0.05 and 0.01 levels of probability, respectively. Standard seeding rate is $110 \mathrm{~kg} \cdot \mathrm{ha}^{-1} 80$ bahiagrass : 20 bermudagrass seed mix. 
between $80 \%$ and $90 \%$ and were not different. Compost treatments had greater total vegetation than bare soil treatments for all but one rating period. Groundcover treatments and 5 $\mathrm{cm}$ compost treatments were generally not different. These data indicate that seeding was ineffective regardless of rate since the $5 \mathrm{~cm}$ compost planted with groundcover became an unseeded $5 \mathrm{~cm}$ compost treatment when the groundcover died after extended drought.

Total quality: Northern site. Double seeding rate treatments had higher quality than standard seeding rates for four rating periods, but otherwise were not different (Table 6). Bare soil treatments were not different than seeded bare soil treatments for all but one rating period. Compost rates of $5 \mathrm{~cm}$ had greater total quality than $10 \mathrm{~cm}$ rates for eight of eighteen rating periods indicating that the lower compost rate may allow for higher quality with lower costs of transporting and application. Compost treatments had greater total quality than bare soil treatments for all
Table 4. Total vegetation and total quality evaluated at 18 months after treatment application at the central Florida site.

\begin{tabular}{lcc}
\hline & $\begin{array}{c}\text { Total } \\
\text { vegetation } \\
(\%)\end{array}$ & $\begin{array}{c}\text { Total } \\
\text { quality }\end{array}$ \\
\hline Breatment & $86 \mathrm{a}^{\mathrm{y}}$ & $7.7 \mathrm{a}$ \\
Erosion mat standard seeding & $62 \mathrm{~b}$ & $5.1 \mathrm{~b}$ \\
Erosion mat double seeding & $60 \mathrm{~b}$ & $5.0 \mathrm{~b}$ \\
Compost, $5 \mathrm{~cm}$, standard seeding & $46 \mathrm{bc}$ & $3.5 \mathrm{bc}$ \\
Compost, $5 \mathrm{~cm}$, double seeding & $54 \mathrm{bc}$ & $4.3 \mathrm{bc}$ \\
Compost, $5 \mathrm{~cm}$, with groundcover & $56 \mathrm{bc}$ & $4.4 \mathrm{bc}$ \\
Compost, $10 \mathrm{~cm}$, standard seeding & $41 \mathrm{c}$ & $3.0 \mathrm{c}$ \\
Compost, $10 \mathrm{~cm}$, double seeding & $52 \mathrm{bc}$ & $4.0 \mathrm{bc}$ \\
Coefficient of variation $(\%)$ & 15.0 & 31.3 \\
\hline
\end{tabular}

${ }^{2}$ Ratings of quality were assessed using a 1 to 9 scale, with $9=$ the highest density, best uniformity, and no undesirable species.

'Means within columns followed by unlike letters are significantly different at the $5 \%$ level by Duncan's multiple range test.

but one rating period. Groundcover treatments and $5 \mathrm{~cm}$ compost treatments were generally not different (Table 7).

Sediment loss. Compost treatments had no measurable sediment loss. Sediment loss for bare soil treatments after the first year of rainfall averaged $10.8 \mathrm{Mg} \cdot \mathrm{ha}^{-1}$. Sediment collected monthly during the last 6 months of the study averaged $2.6 \mathrm{Mg} \cdot \mathrm{ha}^{-1}$ per month (reduced collection area of $12 \mathrm{~m}^{2}$ ). Over the

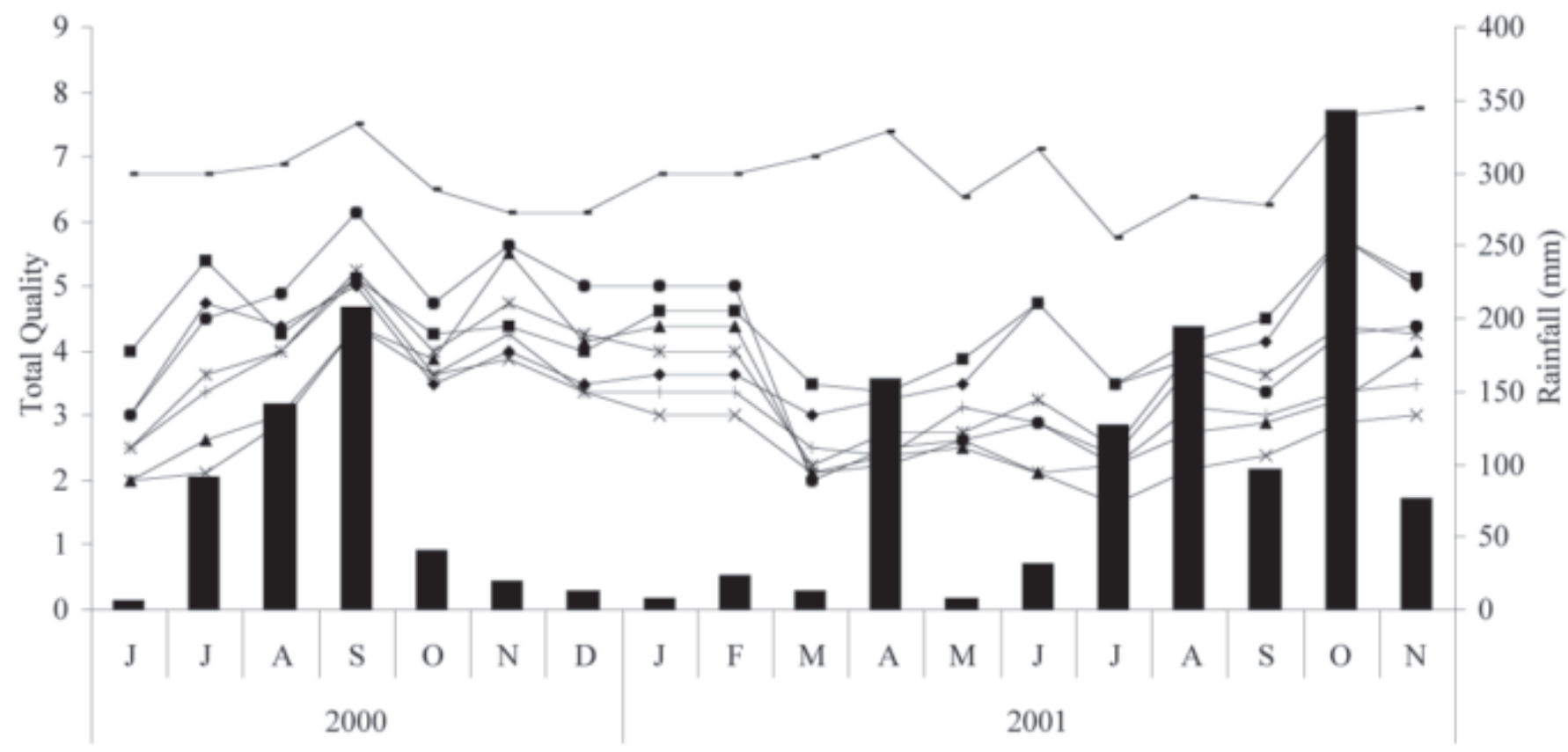

Time (month

Rainfall - Erosion mat double seeding - Erosion mat standatd seeding
$-10 \mathrm{~cm}$ compost double seeding $\rightarrow-10 \mathrm{~cm}$ compost standard seeding $\star-5 \mathrm{~cm}$ compost double seeding
$-5 \mathrm{~cm}$ compost ground cover $\longrightarrow-5 \mathrm{~cm}$ compost standard seeding - Bahiagrass sod

Fig. 2. Total quality ratings and rainfall over 18 months in 2000 and 2001 at the central Florida site. Ratings of total quality were assessed using a 1 to 9 scale, with $9=$ the highest density, best uniformity, and no undesirable species. Nearly all groundcover plants died and were replanted October 2000.

Table 5. Mean squares for the primary dependant variables and interactions at the northern Florida site during 2000 and 2001. Main variable date consisted of monthly evaluations and treatments were vegetation establishment strategies.

\begin{tabular}{lrcr}
\hline Source & df & Total & Total \\
\hline Date & 17 & vegetation & quality \\
Replication & 3 & $6425.90^{* *}$ & $9.1^{* *}$ \\
Treatment & 7 & $6640.33^{* *}$ & $59.2^{* *}$ \\
Date $\times$ replication & 51 & $6855.79^{* *}$ & $73.4^{* *}$ \\
Date $\times$ treatment & 119 & $199.77^{* *}$ & $4.0^{* *}$ \\
Replication $\times$ treatment & 21 & $163.96^{* *}$ & $1.4^{* *}$ \\
Error & 357 & $514.17^{* *}$ & $10.1^{* *}$ \\
Coefficient of variation $(\%)$ & & 53.25 & 1.3 \\
\hline
\end{tabular}

${ }^{* *}$ Significance at the 0.01 level of probability. 
course of a year, this would equate to about three times the amount of sediment collected during the first year (10.8 vs. $\left.31.2 \mathrm{Mg} \cdot \mathrm{ha}^{-1}\right)$.
These differences are likely due to a combination of factors influencing the amount of soil lost from the test plots. At the time of treat- ments application, compost settled on each of the bare soil treatments from adjacent compost treated plots, resulting in decreased sediment

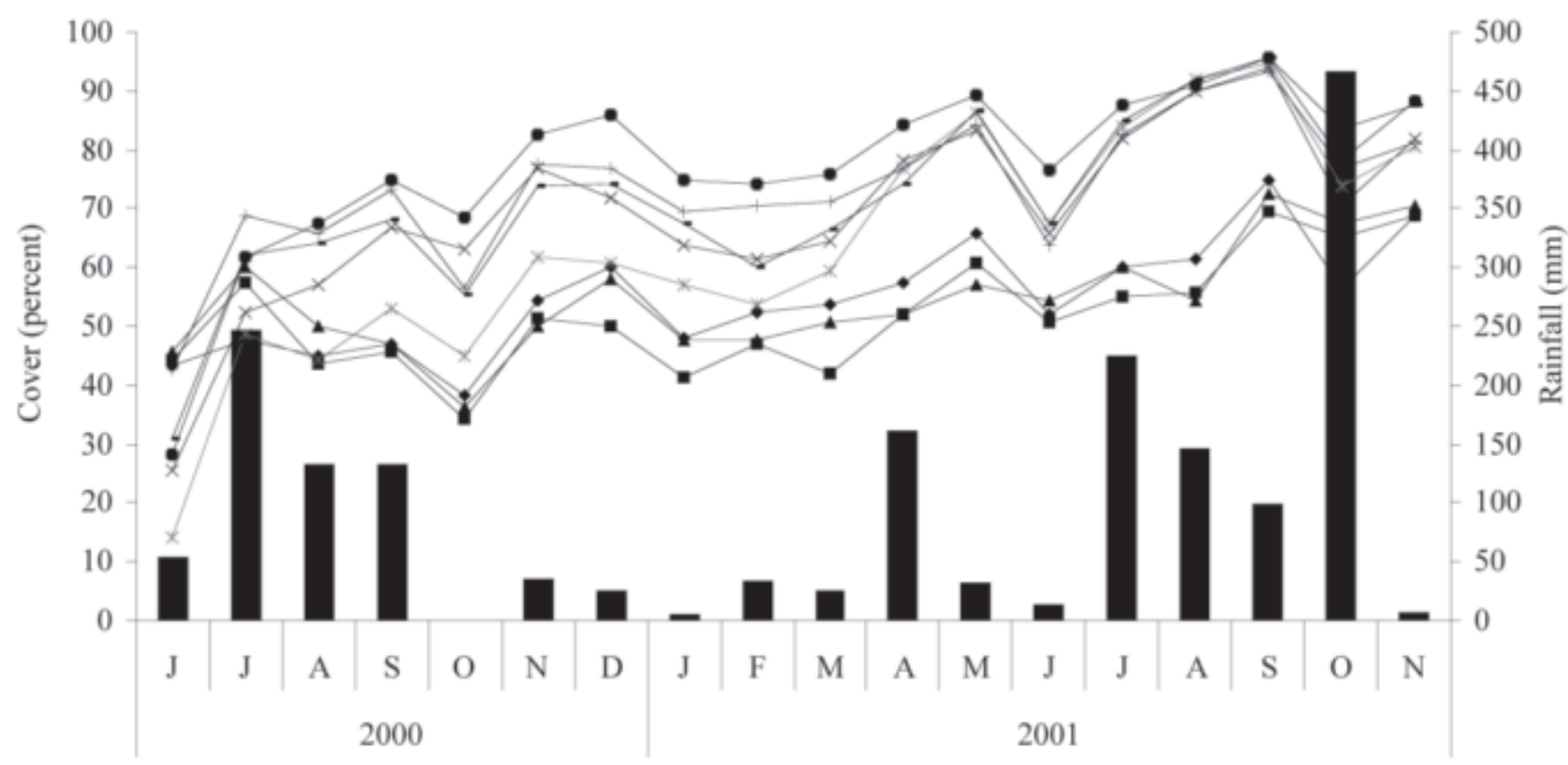

Time (month

Rainfall
- Bare ground standard seeding $\rightarrow-$ Bare ground
$-5 \mathrm{~cm}$ compost double seeding $\rightarrow-$ Bare ground double seeding
$-5 \mathrm{~cm}$ compost ground cover $-5 \mathrm{~cm}$ compost standard seeding

Fig. 3. Percent total vegetation and rainfall over 18 months in 2000 and 2001 at the northern Florida site. Total vegetation included grass and weed species. Nearly all groundcover plants died and were replanted October 2000.

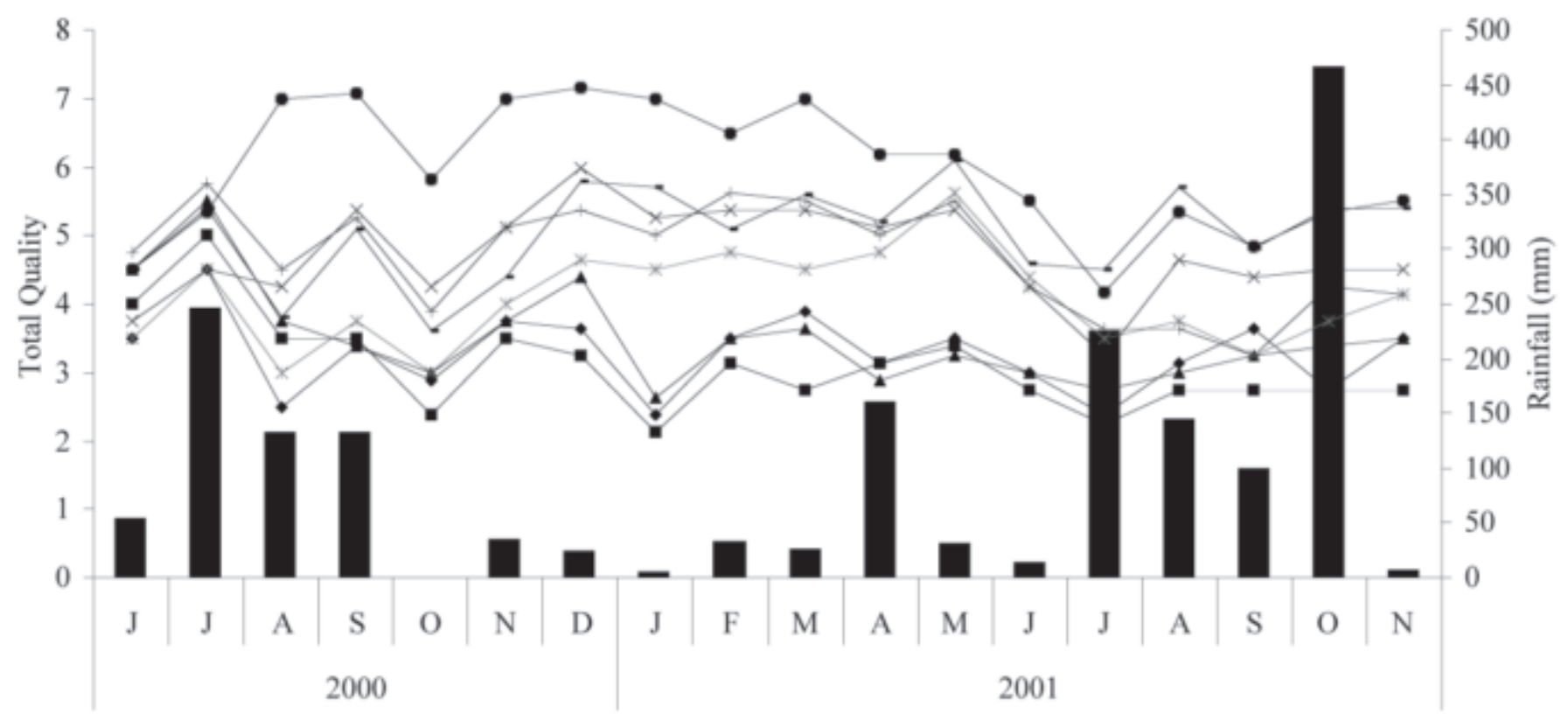

Time (month

\begin{tabular}{|c|c|c|}
\hline & - Bare ground & - Bare ground double seeding \\
\hline re ground standard seeding & $-x-10 \mathrm{~cm}$ compost double seeding & $-x-10$ \\
\hline
\end{tabular}

Fig. 4. Total quality ratings and rainfall over 18 months in 2000 and 2001 at the northern Florida site. Ratings of quality were assessed using a 1 to 9 scale, with $9=$ the highest density, best uniformity, and no undesirable species. Nearly all groundcover plants died and were replanted October 2000. 
Table 6. Single degree of freedom orthogonal contrasts between treatments for total vegetation and total quality at the northern Florida site for $2000-01$.

\begin{tabular}{|c|c|c|c|c|c|c|c|c|c|c|c|c|c|c|c|c|c|c|}
\hline \multirow[b]{3}{*}{ Total vegetation ${ }^{z}$} & \multicolumn{18}{|c|}{ Month } \\
\hline & \multicolumn{7}{|c|}{2000} & \multicolumn{11}{|c|}{2001} \\
\hline & June & July & Aug. & Sept. & Oct. & Nov. & $\overline{\text { Dec. }}$ & Jan. & Feb. & Mar. & Apr. & May & June & July & Aug. & Sept. & Oct. & Nov. \\
\hline Bare vs. compost & $* *$ & NS & $* *$ & $* *$ & $* *$ & $* *$ & $* *$ & $* *$ & $* *$ & $* *$ & $* *$ & $* *$ & $* *$ & $* *$ & $* *$ & $* *$ & $* *$ & $* *$ \\
\hline Double seeding vs. standard & NS & NS & NS & NS & $* *$ & $*$ & NS & NS & NS & NS & NS & NS & NS & NS & NS & NS & NS & NS \\
\hline Compost, 10 vs. $5 \mathrm{~cm}$ & $*$ & $* *$ & $* *$ & $*$ & NS & NS & $*$ & $*$ & NS & $*$ & NS & NS & NS & NS & NS & NS & NS & NS \\
\hline Bare no seed vs. bare seeded & NS & $*$ & NS & NS & NS & NS & NS & NS & NS & NS & NS & NS & NS & NS & NS & NS & NS & NS \\
\hline Bare vs. $5 \mathrm{~cm}$ compost & $* *$ & NS & $* *$ & $* *$ & $* *$ & $* *$ & ** & $* *$ & $* *$ & $* *$ & $* *$ & $* *$ & $* *$ & $* *$ & $* *$ & $* *$ & $*$ & $* *$ \\
\hline $\begin{array}{l}\text { Groundcover vs. } 5 \mathrm{~cm} \text { compost } \\
\text { Total quality }\end{array}$ & $*$ & NS & NS & NS & NS & NS & NS & NS & NS & NS & NS & NS & $*$ & NS & NS & NS & NS & NS \\
\hline Bare vs. composts & $* *$ & NS & $*$ & $* *$ & $* *$ & $* *$ & $* *$ & $* *$ & $* *$ & $* *$ & $* *$ & $* *$ & $* *$ & $* *$ & $* *$ & $* *$ & $* *$ & $* *$ \\
\hline Double seeding vs. standard & NS & NS & $*$ & $*$ & NS & $*$ & NS & NS & NS & NS & $*$ & NS & NS & NS & NS & NS & NS & NS \\
\hline Compost, 10 vs. $5 \mathrm{~cm}$ & ns & NS & $* *$ & $*$ & NS & NS & NS & $*$ & NS & $*$ & NS & NS & NS & $*$ & $* *$ & NS & $*$ & $*$ \\
\hline Bare no seed vs. bare seeded & NS & NS & NS & NS & NS & NS & NS & NS & NS & NS & NS & NS & NS & NS & NS & NS & NS & NS \\
\hline Bare vs. $5 \mathrm{~cm}$ compost & $* *$ & NS & $* *$ & $* *$ & $* *$ & $* *$ & $* *$ & $* *$ & $* *$ & $* *$ & $* *$ & $* *$ & $* *$ & $* *$ & $* *$ & $* *$ & $* *$ & $* *$ \\
\hline Groundcover vs. $5 \mathrm{~cm}$ compost & NS & NS & NS & NS & NS & NS & NS & NS & NS & NS & NS & NS & NS & NS & $* *$ & $*$ & NS & $*$ \\
\hline
\end{tabular}

${ }^{2}$ Total vegetation included grass, weed, and groundcover plants. Most groundcover plants died or were covered by weeds.

${ }^{y}$ Ratings of total quality were assessed using a 1 to 9 scale, with $9=$ the highest density, best uniformity, and no undesirable species.

${ }^{* * * * *}$ Significance at the 0.05 and 0.01 levels of probability, respectively. Standard seeding rate is $110 \mathrm{~kg} \cdot \mathrm{ha}^{-1} 80 \mathrm{bahiagrass}: 20 \mathrm{bermudagrass}$ seed mix.

loss values due to the influence of the compost. The smaller silt fence catchments used during the last 6 months reduced the influence from the bordering plots and allowed more accurate collection and measurement of the eroded soil. The amount of rainfall was also a factor. Rainfall for the first year of the study $(895 \mathrm{~mm})$ was less than half of the total rainfall $(1952 \mathrm{~mm})$ for the 18 months of the experiment.

Greenhouse study. Due to significant date, treatment, and date $\times$ treatment interactions (Table 8), seedling emergence over time is shown in Fig. 5. The number of seedlings for compost with seed incorporated treatments and erosion mat treatments were not different for the first 8 weeks of the experiment (Table 9). Treatments with seed placed on top of the compost performed poorly during this time. These results are likely due to the low irrigation rate $(8 \mathrm{~mm} / 24 \mathrm{~h})$ applied initially. Most seeds were suspended in the coarse compost and could not imbibe enough water to germinate. Germination results of erosion mat treatments whether seeded above or below were not different throughout the study. Seed placed above erosion mats tended to settle below the mat over time due to movement initiated by irrigation water. After irrigation intensity was increased to simulate heavy summer rainfall (Fig. 5), treatments where seed was placed on top of the compost had a greater number of seedlings than all other treatments. The delay in seedling growth may be attributed to the initial lack of sufficient moisture necessary for seedling germination at low irrigation intensities. Seedling growth of the compost seeded above treatments exceeded all other treatments at the conclusion of the study.

\section{Conclusions}

Results from the field study indicate that compost mulch can effectively control erosion, but does not necessarily facilitate the growth and establishment of turfgrass. It can provide slope stability for periods of at least 18 months and probably longer with or without vegetative growth and may improve the visual quality of roadside slopes. This study was conducted during drought conditions, and seeding was mostly ineffective for any treatments. More

Table 7. Total vegetation and total quality at 18 months after treatment application at the northern Florida site.

\begin{tabular}{lcc}
\hline & $\begin{array}{c}\text { Total } \\
\text { vegetation } \\
(\%)\end{array}$ & $\begin{array}{c}\text { Total } \\
\text { quality }\end{array}$ \\
Treatment & $69 \mathrm{~b}^{\mathrm{y}}$ & $3.5 \mathrm{bc}$ \\
Bare ground control & $70 \mathrm{~b}$ & $3.5 \mathrm{bc}$ \\
Bare ground standard seeding & $69 \mathrm{~b}$ & $2.8 \mathrm{c}$ \\
Bare ground double seeding & $88 \mathrm{a}$ & $5.4 \mathrm{a}$ \\
Compost, $5 \mathrm{~cm}$, standard seeding & $88 \mathrm{a}$ & $5.5 \mathrm{a}$ \\
Compost, $5 \mathrm{~cm}$, double seeding & $81 \mathrm{ab}$ & $4.1 \mathrm{abc}$ \\
Compost, $5 \mathrm{~cm}$, with groundcover & $81 \mathrm{ab}$ & $4.1 \mathrm{abc}$ \\
Compost, $10 \mathrm{~cm}$, standard seeding & $82 \mathrm{ab}$ & $4.5 \mathrm{ab}$ \\
Compost, $10 \mathrm{~cm}$, double seeding & 11.8 & 23.4 \\
Coefficient of variation (\%) & & ( $\%$ greatest density, best uniformity, and
\end{tabular}

${ }^{2}$ Ratings of quality were assessed using a 1 to 9 scale, with $9=$ the greatest density, best uniformity, and no undesirable species.

'Means within columns followed by unlike letters are significantly different at the $5 \%$ level by Duncan's multiple range test.

Table 8. Mean squares for the primary dependant variables and interactions for the greenhouse study.

\begin{tabular}{lrc}
\hline Source & df & Mean squares \\
\hline Date & 5 & $1549.79^{* * *}$ \\
Replication & 3 & $50.50^{*}$ \\
Treatment & 3 & $121.75^{* *}$ \\
Date $\times$ replication & 15 & 13.49 \\
Date $\times$ treatment & 15 & $126.88^{* *}$ \\
Replication $\times$ treatment & 9 & 80.49 \\
Error & 45 & 19.83 \\
Coefficient of variation $(\%)$ & & 32.3
\end{tabular}

${ }^{*, * *}$ Significant at the 0.05 and 0.01 levels of probability, respectively.

typical weather with normal rainfall amounts would have likely resulted in greater grass establishment.

Results from the greenhouse seeding experiment indicate that seed incorporation into composted yard waste mulch may not be necessary during periods of abundant rainfall. However, during periods of low rainfall, seed germination will be greater when incorporated into the compost either by hand raking or mixing the seed at depths less than $4 \mathrm{~cm}$ with the compost prior to application. This study indicates that erosion control mats can be seeded either above or below without affecting seed germination.

\section{Literature Cited}

Bremner, J.M. and C.S. Mulvaney. 1982. Total nitrogen, p. 595-624. In: A.L. Page et al. (eds.). Methods of soil analysis. Part 2. 2nd ed. ASA-SSSA Monogr. 9.

Carroll, M.J. 1992. Erosion control: Turf and geosynthetics. Grounds Maint. 27(9):26-30.
Collier, B.J., J.L. Thames, J.R. Collier, M.M. Elsunni, E.W. Bush, and D.P. Shepard. 1997. Turfgrass establishment using experimental and commercial erosion control mats. La. Agr. 40(1):28-29.

Ettlin, L. and B. Stewart. 1993. Yard debris compost for erosion control. Biocycle. 34(12):46-47.

Florida Department of Transportation. 2000. Standard specifications for road and bridge construction. Fla. Dept. Transportation Maps and Publ., Tallahassee.

Giusquiani, P.L., M. Pagliai, G. Gigliotti, D. Businelli, and A. Benetti. 1995. Urban waste compost: effects on physical, chemical, and biochemical soil properties. J. Environ. Qual. 24:175-182.

He, X., S.J. Traina, and T.J. Logan. 1992. Chemical properties of municipal solid waste composts. J. Environ. Qual. 21:318-329.

Kostewicz, S.R. 1993. Pole bean yield as influenced by composted yard waste soil amendments. Proc. Fla. State Hort. Soc. 106:206-208.

Krenitsky, E.C., M.J. Carroll, R.L. Hill, and J.M. Krouse. 1998. Runoff and sediment losses from natural and man-made erosion control materials. Crop Sci. 1998 38:1042-1046.

McLean, E.O. 1982. Soil pH and lime requirements, 


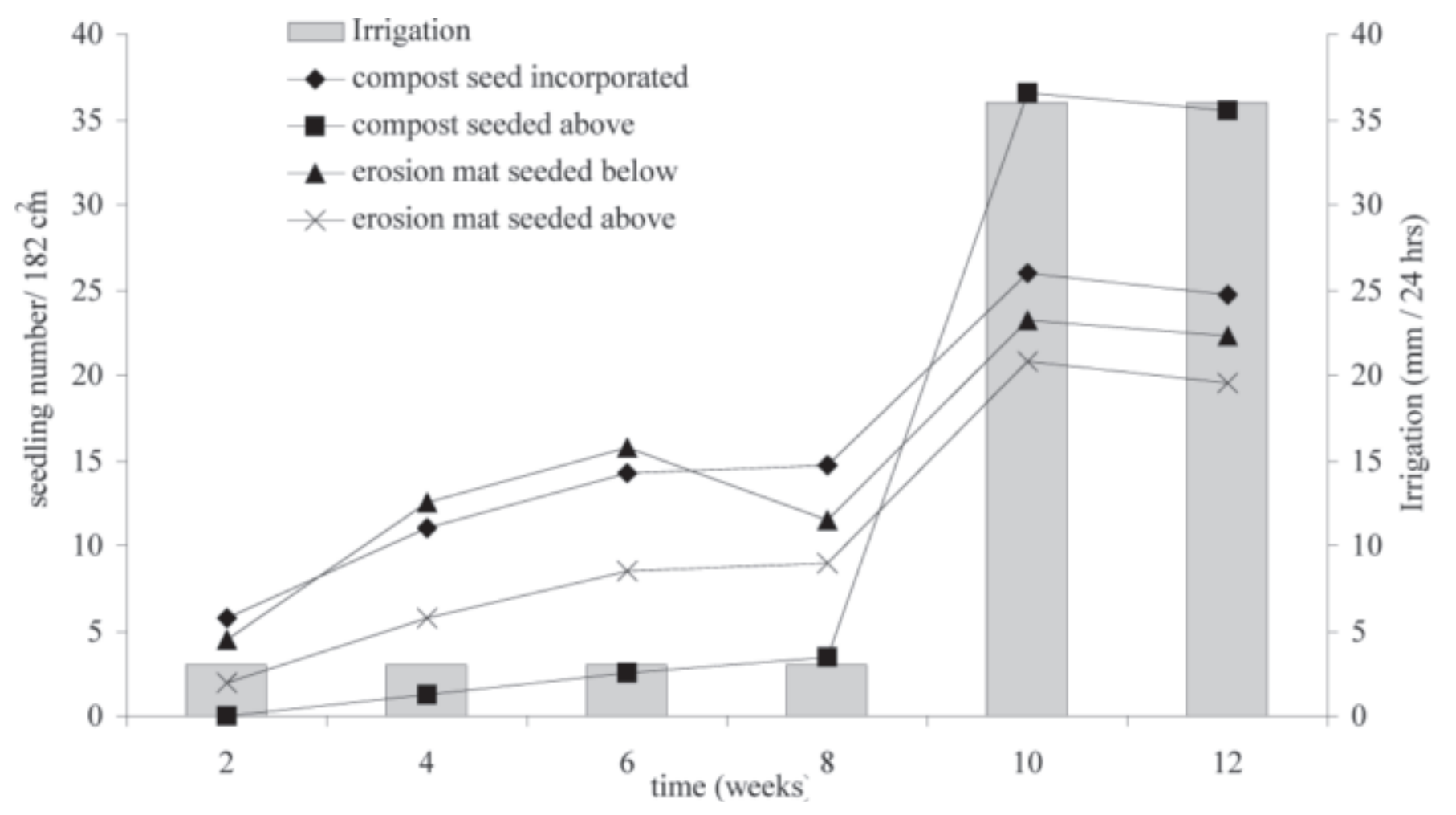

Fig. 5. Effects of seed placement and irrigation on germination and emergence of turfgrass seedlings grown in a greenhouse over 12 weeks. Irrigation amount was increased immediately following 8 week seedling count.

Table 9. Number of turfgrass seedlings over time as affected by seed placement in relation to an erosion mat or compost for the greenhouse study.

\begin{tabular}{lcccccc}
\hline & \multicolumn{5}{c}{ Week } \\
\cline { 2 - 7 } Treatment $^{z}$ & 2 & 4 & 6 & 8 & 10 & 12 \\
\hline MSB & $5 \mathrm{ab}^{y}$ & $13 \mathrm{a}$ & $16 \mathrm{a}$ & $12 \mathrm{ab}$ & $23 \mathrm{~b}$ & $22 \mathrm{~b}$ \\
MSA & $2 \mathrm{bc}$ & $6 \mathrm{ab}$ & $9 \mathrm{ab}$ & $9 \mathrm{ab}$ & $21 \mathrm{~b}$ & $20 \mathrm{~b}$ \\
CSA & $0 \mathrm{c}$ & $1 \mathrm{~b}$ & $3 \mathrm{~b}$ & $3 \mathrm{~b}$ & $37 \mathrm{a}$ & $36 \mathrm{a}$ \\
CSIN & $6 \mathrm{a}$ & $11 \mathrm{a}$ & $14 \mathrm{a}$ & $15 \mathrm{a}$ & $26 \mathrm{~b}$ & $25 \mathrm{~b}$ \\
\hline
\end{tabular}

${ }^{2} \mathrm{MSB}=$ erosion mat seeded below; MSA = erosion mat seeded above; $\mathrm{CSA}=$ compost seeded above; $\mathrm{CSIN}=$ compost seed incorporated.

yMeans within columns followed unlike letters are significantly different at the $5 \%$ level by Duncan's multiple range test.

p. 199-224. In: A.L. Page et al. (eds.). Methods of soil analysis. Part 2. 2nd ed. ASA-SSSA Agron. Monogr. 9.
Morris, K.N. and R.C. Shearman. 2001. NTEP turfgrass evaluation guidelines. 7 July 2005. http://www.ntep.org/pdf/ratings.pdf.
Mutchler, C.K., C.E. Murphree, and K.C. 1994. McGregor. Laboratory and field plots for erosion research. Soil erosion research methods. St. Lucie Press, Delray Beach, FL.

Oshins, C. and D. Block. 2000. Feedstock composition at composting sites. Biocycle 41(9):31-34.

Robinson, C.A., M. Ghaffarzadeh, and R.M. Cruse. 1996. Vegetative filter strip effects on sediment concentrations in cropland runoff. J. Soil and Water Cons. 50(3):227-230.

Stevens, J.M. and S.R. Kostewicz. 1992. Organic soil amendments for Florida vegetable gardens. Proc. Fla. State Hort. Soc. 105:263-267.

Stevens, J.M. and S.R. Kostewicz. 1994. Response of cucumber to organic soil amendments. Proc. Fla. State Hort. Soc. 107:382-384. 